\title{
PENGARUH KEBIJAKAN UTANG PADA NILAI PERUSAHAAN DENGAN UKURAN PERUSAHAAN SEBAGAI VARIABEL MODERASI
}

\author{
I Pande Putu Suwisnaya \\ Komang Ayu Krisnadewi \\ Email : komangayukrisnadewi@gmail.com \\ Fakultas Ekonomi dan Bisnis Universitas Udayana
}

\begin{abstract}
The purpose of this study is to provide empirical evidence about the effect of debt policy on the company's value where the size of the company as a moderating variable. This study was performed on companies listed in Indonesia Stock Exchange in 2012-2015. The total sample of 88 companies with a total number of observations as much as 352 observations. The analysis technique used is the moderated regression analysis (MRA). The company's value in this study is proxied by the price book value (PBV), while the debt policy is proxied by debt to equity ratio (DER), and the size of the company is proxied by the natural logarithm of total assets. Based on the analysis found that the debt policy significant positive effect on the value of the company, which weakens the relationship between the size of the company's debt policy on the value of the company.
\end{abstract}

Key Words: $\quad$ company's value, debt policy, PBV, DER, company's size

\section{PENDAHULUAN}

Setiap pemegang saham perusahaan, selaku pemilik perusahaan, senantiasa berharap agar nilai perusahaannya tinggi. Kemakmuran pemilik perusahaan dapat dilihat dari nilai perusahaan. (Nurhayati, 2013). Menurut Kontesa (2015), nilai perusahaan akan tercermin dari harga sahamnya. Nilai perusahaan menjadi gambaran kepercayaan dari masyarakat terhadap perusahaan, dan diperoleh setelah melalui suatu proses kegiatan selama beberapa tahun, yaitu sejak perusahaan tersebut didirikan sampai dengan saat ini (Sukirni, 2012). Memaksimalkan nilai perusahaan dapat dicapai melalui pelaksanaan fungsi manajemen keuangan, dimana suatu kebijakan atau keputusan keuangan yang diambil akan Jurnal IImiah Wahana Akuntansi mempengaruhi keputusan keuangan lainnya dan berdampak pada nilai perusahaan (Juhandi, et al., 2013).

Integritas informasi laporan keuangan yang mencerminkan nilai perusahaan merupakan sinyal positif yang dapat mempengaruhi opini investor dan kreditor atau pihak-pihak lain yang berkepentingan (Fenandar, 2012). Teori sinyal menyatakan bahwa perusahaan yang berkualitas baik dengan sengaja akan memberikan sinyal pada pasar, sehingga pasar diharapkan dapat membedakan perusahaan yang berkualitas baik dan buruk. Sinyal biasanya berupa informasi yang dipublikasi oleh perusahaan. Investor dapat melakukan analisis terhadap suatu perusahaan melalui informasi yang 
dipublikasi oleh pihak manajemen perusahaan.

Pengeluaran investasi memberikan sinyal positif tentang pertumbuhan perusahaan di masa yang akan datang, sehingga meningkatkan harga saham sebagai indikator nilai perusahaan. Mardyati, dkk. (2012) menyatakan bahwa jika manajer memiliki keyakinan bahwa prospek perusahaannya baik, maka manajer tersebut akan mengomunikasikan pengeluaran investasinya kepada para investor. Selanjutnya, perusahaan dengan prospek menguntungkan akan mencoba menghindari penjualan saham dan mengusahakan modal baru dengan caracara lain seperti dengan menggunakan utang. Manajer dapat menggunakan utang yang lebih banyak, yang nantinya berperan sebagai sinyal yang lebih terpercaya karena perusahaan yang meningkatkan utang bisa dipandang sebagai perusahaan yang yakin dengan prospek perusahaan di masa yang akan datang (Hanarista, 2016). Investor diharap akan menangkap sinyal tersebut, yakni sinyal bahwa perusahaan mempunyai prospek yang prospektif di masa depan. Jadi, dapat disimpulkan utang merupakan sinyal positif dari perusahaan.

$$
\text { Kebijakan utang merupakan }
$$
kebijakan perusahaan tentang seberapa jauh sebuah perusahaan menggunakan pendanaan utang (Mardyati, $d k k ., 2012$ ). Dalam kenyataanya perusahaan dituntut menentukan kebijakan struktur modal yang optimal karena pada dasarnya sumber pendanaan berdampak pada nilai perusahaan (Meythi, 2012). Struktur modal merupakan komposisi pendanaan sendiri (ekuitas) dan utang. Semakin tinggi proporsi utang maka semakin tinggi harga saham, namun pada titik tertentu peningkatan utang akan menurunkan nilai perusahaan karena manfaat yang diperoleh dari penggunaan utang lebih kecil daripada biaya yang ditimbulkannya (Jusriani dan Rahardjo, 2013). Hasil penelitian terkait kebijakan utang terhadap nilai perusahaan dilakukan oleh beberapa peneliti dengan hasil yang beragam.

Altan and Ferhat (2011) serta Antwi, et al. (2012) dalam penelitiannya mengindikasikan bahwa utang mempunyai pengaruh positif signifikan dan paling dominan terhadap nilai perusahaan. Ogbulu and Francis (2012) juga menyimpulkan bahwa utang jangka panjang (Long term debt) ditemukan menjadi penentu utama dari nilai perusahaan. Itturiaga and Vicente (2010), Sukirni (2012), Sudiyatno dkk (2012) serta Hidayat (2013) membuktikan bahwa kebijakan utang berpengaruh positif terhadap nilai perusahaan. Sebaliknya, Nainggolan dan Listiadi (2014), Setiabudi and Diah (2012) menemukan bahwa kebijakan utang berpengaruh negatif signifikan terhadap nilai perusahaan. Penelitian Apergis and Sorros (2010) menunjukkan bahwa variable long term leverage obligation berpengaruh negatif dan signifikan terhadap nilai perusahaan. Berbeda halnya dengan Mardyati dkk (2012), Jusriani dan Rahardjo (2013), serta 
Hanarista (2016) yang menemukan bahwa kebijakan utang tidak berpengaruh terhadap nilai perusahaan. Ketidakkonsistenan hasil penelitian sebelumnya, mendorong peneliti melakukan penelitian ini yang bertujuan untuk menemukan bukti empiris pengaruh kebijakan utang pada nilai perusahaan dengan menggunakan ukuran perusahaan sebagai pemoderasi.

\section{KAJIAN PUSTAKA， KERANGKA PEMIKIRAN, DAN HIPOTESIS}

Pecking order theory menetapkan suatu urutan keputusan pendanaan dimana para manajer pertama kali akan memilih untuk menggunakan laba ditahan, utang dan penerbitan saham sebagai pilihan terakhir (Hidayat, 2013). Penggunaan utang lebih disukai karena biaya yang dikeluarkan untuk utang lebih murah dibandingkan dengan biaya penerbitan saham. Pecking order theory menjelaskan mengapa perushaan-perusahaan yang profitable (menguntungkan) umumnya meminjam dalam jumlah yang sedikit. Hal tersebut bukan karena perusahaan mempunyai target debt ratio yang rendah, tetapi karena memerlukan external financing yang sedikit. Sedangkan perusahaan yang kurang profitable cenderung mempunyai utang yang lebih besar karena dana internal tidak cukup dan utang merupakan sumber eksternal yang lebih disukai.

Kebijakan utang merupakan kebijakan perusahaan tentang seberapa jauh sebuah perusahaan menggunakan pendanaan utang (Mardyati, $d k k$, , 2011). Utang adalah instrumen yang sangat sensitif terhadap perubahan nilai perusahaan. Semakin tinggi proporsi utang maka semakin tinggi harga saham, namun pada titik tertentu peningkatan utang akan menurunkan nilai perusahaan karena manfaat yang diperoleh dari penggunaan utang lebih kecil daripada biaya yang ditimbulkannya (Jusriani dan Rahardjo, 2013). Dalam pengambilan keputusan akan penggunaan utang perusahaan harus mempertimbangkan biaya tetap yang muncul berupa bunga, dimana nantinya akan menimbulkan ketidakpastian pengembalian bagi para pemegang saham.

Trade off theory menganggap bahwa penggunaan utang 100 persen sulit dijumpai (Hidayat, 2013). Trade-off theory ini menunjukkan adanya keseimbangan antara manfaat penghematan pajak melalui pendanaan dengan utang dan biaya kebangkrutan yang lebih tinggi akibat penggunaan utang. Ini menjelaskan bahwa perusahaan yang membayar pajak tinggi sebaiknya lebih banyak menggunakan utang dibandingkan dengan perusahaan yang membayar pajak rendah (Wiliandri, 2011). Kenyataannya semakin banyak utang, maka semakin tinggi beban yang harus ditanggung. Satu hal yang penting bahwa dengan meningkatnya utang, maka semakin tinggi probabilitas kebangkrutan.

Dilihat dari teori sinyal, terdapat reaksi saham jika terjadi peningkatan dan penurunan utang perusahaan. Pada 
umumnya, pendanaan dengan utang merupakan sinyal yang positif. Karena jika perusahaan mempunyai kesempatan investasi yang menguntungkan, maka perusahaan akan membutuhkan dana tambahan untuk memenuhi rencana investasi perusahaan. Oleh karena itu investor memandang perusahaan yang meningkatkan proporsi utang merupakan perusahaan yang memiliki prospek perusahaan yang bagus dan otomatis ketika perusahaan dipandang memiliki prospek yang baik maka harga saham perusahan akan mengalami peningkatan dan secara langsung nilai perusahaan meningkat. Jadi dalam hal ini akan sangat menguntungkan bagi stockholder untuk menggunakan utang dibandingkan menerbitkan saham baru yang dianggap sebagai sinyal negatif sehingga menurunkan harga saham. Biaya dalam menerbitkan saham juga tinggi, sehingga pendanaan dengan menerbitkan saham baru akan sangat mahal dibandingkan dengan pendanaan dengan utang. Di satu sisi, peningkatan utang dapat meningkatkan leverage, sehingga meningkatkan kemungkinan kesulitan keuangan atau kebangkrutan. Namun tingkat leverage yang lebih tinggi menunjukkan keyakinan yang lebih tinggi dari manajer terhadap kinerja perusahaan di masa depan (Vo and Van, 2014). Menurut Cheng and Zuwei (2011) nilai perusahaan akan bervariasi dengan penggunaan tingkat utang yang berbeda. Hal ini didukung penelitian empiris tentang pengaruh kebijakan utang terhadap nilai perusahaan. Altan and Ferhat (2011) serta Antwi, et al. (2012) dalam penelitiannya mengindikasikan bahwa utang mempunyai pengaruh positif dan signifikan dan paling dominan terhadap nilai perusahaan. Ogbulu and Francis (2012) juga menyimpulkan bahwa utang jangka panjang (Long term debt) ditemukan menjadi penentu utama dari nilai perusahaan. Itturiaga and Vicente (2010), Sukirni (2012), Sudiyatno dkk (2012) serta Hidayat (2013) membuktikan bahwa kebijakan utang berpengaruh positif terhadap nilai perusahaan.

$\mathrm{H}_{1}$ : Kebijakan utang berpengaruh positif pada nilai perusahaan

Ukuran perusahaan adalah suatu skala dimana dapat diklasifikasikan besar kecilnya perusahaan menurut berbagai cara antara lain dengan total aktiva, log size, nilai pasar saham, dan lain-lain (Prasetyorini, 2013). Sedangkan menurut Rizqia, et al. (2013) ukuran perusahaan adalah tingkat untuk menunjukkan perkembangan perusahaan dalam bisnis. Besar kecilnya perusahaan akan mempengaruhi kemampuan dalam menanggung risiko yang mungkin timbul dari berbagai situasi yang dihadapi perusahaan. Selain itu ukuran perusahaan turut menentukan tingkat kepercayaan investor. Yao, et al. (2011) menyatakan bahwa semakin besar suatu perusahaan, maka perusahaan tersebut akan semakin 
disorot oleh para stakeholder. Bahkan perusahaan besar yang memiliki total aktiva dengan nilai aktiva yang cukup besar dapat menarik investor untuk menanamkan modalnya pada perusahaan tersebut.

Ukuran perusahaan menjadi faktor yang dipertimbangkan dalam menentukan level utang perusahaan. Perusahaan besar cenderung lebih mudah untuk memperoleh pinjaman dari pihak ketiga, karena kemampuan untuk mengakses ke pihak lain atau jaminan yang dimiliki berupa aset bernilai besar dibandingkan perusahaan kecil (Faisal, 2004). Penelitian yang dilakukan Titman and Wessels (1988) serta Sudiyatno dan Sari (2013) menemukan bahwa level utang perusahaan dipengaruhi oleh ukuran perusahaan, berbeda dengan hasil Margaretha (2014) bahwa ukuran perusahaan tidak berpengaruh pada leverage.

Ukuran perusahaan dapat dilihat dari total assets yang dimiliki oleh perusahaan yang dapat dipergunakan untuk kegiatan operasi perusahaan (Prasetyorini, 2013). Besar kecilnya perusahaan akan mempengaruhi kemampuan dalam menanggung risiko yang mungkin timbul dari berbagai situasi yang dihadapi perusahaan. Perusahaan yang besar juga dipercaya dapat menyelesaikan kesulitankesulitan keuangan yang dihadapinya daripada perusahaan kecil. Sehingga ketika perusahaan mengambil kebijakan utang publik akan melihatnya sebagai hal positif sehingga mampu meningkatkan nilai perusahaan.

Hasil penelitian dari Rizqia, et al. (2013) menyimpulkan bahwa perusahaan besar dapat menghasilkan nilai perusahaan yang tinggi. Secara teori, hal tersebut didasarkan pada kemudahan akses perusahaan besar untuk mendapatkan pendanaan eksternal. Seperti kemudahan untuk mengakses ke pasar modal yang berarti perusahaan memiliki fleksibilitas dan kemampuan untuk mendapatkan dana, karena kemudahan aksesbilitas ke pasar modal dan kemapuannya untuk memunculkan dana lebih besar. Perusahaan besar juga memiliki aktiva yang besar yang dapat dijaminkan dalam sumber pendanaan.

$\mathrm{H}_{2}$ : Ukuran perusahaan memperkuat pengaruh kebijakan utang pada nilai perusahaan.

\section{OBJEK DAN METODOLOGI PENELITIAN}

Penelitian ini menggunakan data kuantitatif yang berasal dari data sekunder berupa laporan keuangan perusahaan manufaktur periode 2012-2015 dan diperoleh dari website (ww.idx.co.id). Populasi dalam penelitian ini yaitu seluruh perusahaan manufaktur yang terdaftar di Bursa Efek Indonesia (BEI) dari tahun 2012-2015. Metode penentuan sampel yang digunakan adalah nonprobability sampling dengan teknik purposive sampling dengan kriteria: 1) Perusahaan 
manufaktur yang sudah dan masih terdaftar di Bursa Efek Indonesia tahun 2012 sampai dengan 2015. 2) Perusahaan manufaktur yang telah menerbitkan laporan keuangan selama 4 tahun berturutturut, yaitu tahun 2012 sampai dengan 2015, dan berakhir pada tanggal 31 Desember. 3) Perusahaan manufaktur yang memiliki data keuangan lengkap untuk menghitung variabel-variabel dalam penelitian selama periode pengamatan. 4) Perusahaan manufaktur yang menggunakan rupiah dalam laporan keuangannya. 5) Perusahaan manufaktur yang tidak mengalami defisit modal selama periode pengamatan. Berdasarkan kriteria tersebut, diperoleh jumlah perusahaan yang memenuhi kriteria penentuan sampel sebanyak 88 perusahaan dan observasian selama 4 tahun dari tahun 2012 sampai dengan tahun 2015 menjadi sebanyak 352. Desain penelitian ini digambarkan pada gambar 1 .

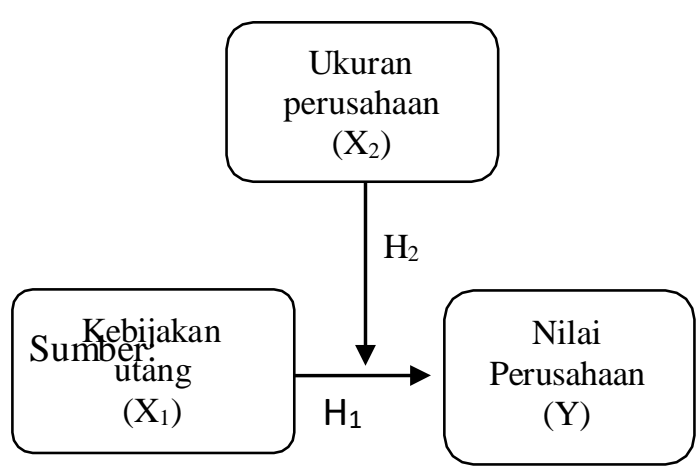

Data diolah, 2016

\section{Gambar 1. Desain Penelitian}

Nilai perusahaan dalam penelitian ini didefinisikan sebagai nilai pasar karena nilai perusahaan dapat memberikan kemakmuran pemegang saham secara maksimum apabila harga saham perusahaan meningkat (Hasnawati, 2005). Mengacu pada penelitian Fenandar (2012), nilai perusahaan dalam penelitian ini diproksikan dengan Price Book Value (PBV). Rasio ini dipilih sebab PBV sangat berguna untuk menentukan saham-saham apa saja yang mengalami undervalued, overvalued, wajar, sehingga dapat menentukan strategi investasi yang sesuai dengan harapan investor untuk memperoleh keuntungan yang tinggi. Selain itu PBV digunakan dalam penelitian ini karena menggambarkan seberapa besar pasar menghargai nilai buku saham suatu perusahaan. Semakin tinggi PBV, maka semakin baik karena pasar percaya akan prospek perusahaan. Sebaliknya, semakin rendah PBV, maka semakin buruk, karena pasar tidak percaya akan prospek perusahaan.

\section{Price to Book Value $(\mathrm{PBV})=$}

Harga per lembar saham dilihat dari harga saham pada saat penutupan bursa (Agustina, 2008). Nilai buku per lembar saham merupakan perbandingan dari ekuitas pemegang saham dengan jumlah saham yang beredar (Putri, 2012).

Proksi dari kebijakan utang pada penelitian ini adalah Debt to Equity Ratio (DER) yang mengacu pada penelitian Mardiyati, dkk. (2012) dan Sukirni (2012). DER (Debt to Equity Ratio) yang 
merupakan rasio yang menggambarkan komposisi/struktur modal perusahaan yang digunakan sebagai sumber pendanaan usaha (Sukirni, 2012). Tujuan dari rasio ini adalah untuk mengukur kemampuan perusahaan dalam membayar utang-utang yang dimilikinya dengan modal atau ekuitas yang ada (Mardiyati, $d k k$., 2012).

Dalam penelitian ini, ukuran perusahaan dinilai dengan logaritma natural of total assets. Logaritma natural of Total Assets ini digunakan untuk mengurangi perbedaan signifikan antara ukuran perusahaan yang terlalu besar dengan ukuran perusahaan yang terlalu kecil, maka nilai total aset dibentuk menjadi logaritma natural, konversi bentuk logaritma natural ini bertujuan untuk membuat data total assets terdistribusi normal. Secara umum ukuran perusahaan dapat dirumuskan sebagai berikut (Pradana, 2015 dan Nurhayati, 2013) :

$$
\text { Size }=\text { Ln of total aktiva }
$$

\begin{tabular}{|l|l|l|l|l|}
\hline & Minimum & Maximum & Mean & $\begin{array}{l}\text { Std. } \\
\text { Deviation }\end{array}$ \\
\hline PBV &, 08 & 56,06 & 3,4389 & 7,48169 \\
DER &, 01 & 152,49 & 1,6763 & 8,20898 \\
SIZE & 11,40 & 19,32 & 14,3077 & 1,60664 \\
DERxSIZE &, 15 & 2057,09 & 23,8531 & 110,92662 \\
\hline
\end{tabular}

Data penelitian dianalisis dengan menggunakan model Moderated Regression Analysis (MRA) yang diolah menggunakan SPSS 15.0 for windows.

Persamaan analisis regresi tersebut dapat dirumuskan sebagai berikut :

$Y=\alpha+\beta_{1} X_{1}+\beta_{2} X_{2}+\beta_{3} X_{1} X_{2}+. .(4)$

Keterangan:

$\mathrm{Y}=$ Nilai Perusahaan

$\mathrm{X}_{1}=$ Kebijakan Utang

$\mathrm{X}_{2} \quad=$ Ukuran Perusahaan

$\mathrm{B}=$ Koefisien regresi

$\varepsilon=$ Standar error

$\alpha \quad=$ Konstant

Sebelum melakukan uji MRA terlebih dahulu dilakukan uji asumsi klasik yang terdiri dari uji normalitas, uji autokorelasi dan uji heterokedastisitas.

\section{PEMBAHASAN}

Statistik deskriptif disajikan untuk memberikan informasi mengenai karakteristik variabel-variabel penelitian, yaitu jumlah sampel, nilai maksimum, nilai minimum, nilai rata-rata, dan standar deviasi. Peneliti melakukan pengobatan data dengan transformasi data ke dalam bentuk logaritma 10. Hal tersebut dilakukan untuk mendapatkan model yang lolos uji asumsi klasik. Hasil statistik deskriptif penelitian ini dapat dilihat pada tabel 1.

Tabel 1. Hasil Uji Statistik Deskriptif 
Sumber: data diolah, 2017

\section{Moderated Regression Analysis} (MRA) merupakan teknik analisis data yang digunakan untuk mengetahui pengaruh variabel independen terhadap variabel dependennya dan kemampuan variabel pemoderasi dalam memoderasi pengaruh variabel independen terhadap variabel dependennya.

Tabel 2. Hasil Moderated Regression Analysis

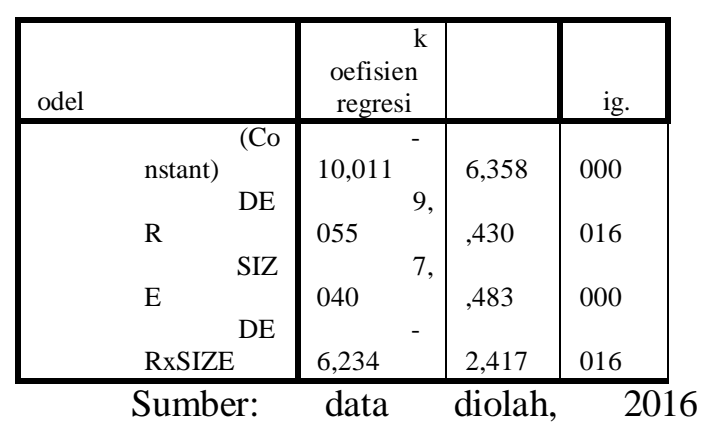

Berdasarkan Tabel 2, maka hasil uji $\mathrm{t}$ dapat diartikan sebagai berikut. Variabel kebijakan utang $\left(\mathrm{X}_{1}\right)$ yang diproksikan dengan debt to equity ratio(DER) memiliki t hitung sebesar 2,430 dengan nilai signifikansi 0,016 . Nilai signifikansi sebesar 0,016 lebih kecil dari tingkat signifikansi 0.05 , yang memiliki arti bahwa kebijakan utang $\left(\mathrm{X}_{1}\right)$ secara parsial berpengaruh signifikan pada nilai perusahaan (Y). Hal ini menunjukan bahwa kebijakan utang berpengaruh positif signifikan pada nilai perusahaan, sehingga $\mathrm{H}_{1}$ diterima. Arah koefisien regresi positif menunjukan bahwa semakin tinggi nilai DER maka nilai perusahaan yang diproksikan dengan price book value akan meningkat.

Hasil ini sesuai dengan teori pecking order dimana para manajer akan memilih untuk menggunakan utang terlebih dahulu dibandingkan penerbitan saham. Penggunaan utang lebih disukai karena biaya yang dikeluarkan untuk utang lebih murah dibandingkan dengan biaya penerbitan saham. Oleh karenanya, teori trade off dimana terdapat pertukaran antara manfaat dan biaya dari penggunaan utang akan selalu dipertimbangkan.

Peningkatan penggunaan utang perusahaan akan memberikan sinyal bagi investor sehingga terdapat reaksi pada nilai saham. Pendanaan dengan utang merupakan sinyal yang positif sebab investor percaya bahwa jika perusahaan mempunyai kesempatan investasi yang menguntungkan, maka perusahaan akan membutuhkan dana tambahan untuk memenuhi rencana investasi perusahaan. Tingkat leverage yang lebih tinggi menunjukkan keyakinan yang lebih tinggi dari manajer terhadap kinerja perusahaan di masa depan. Sebaliknya, penerbitan saham baru sebagai sumber pendanaan justru dianggap sebagai sinyal negatif mengingat biaya penerbitan saham cukup tinggi karena berdampak pada komposisi pemilikan perusahaan sehingga dapat menurunkan harga saham.

Hasil penelitian ini sesuai dengan penelitian yang dilakukan Itturiaga and Vicente (2010), Altan and Ferhat (2011) Antwi, et al. (2012), Ogbulu and Francis 
(2012), Sukirni (2012), Sudiyatno dkk

(2012) serta Hidayat (2013) yang membuktikan bahwa kebijakan utang berpengaruh positif terhadap nilai perusahaan.

Berdasarkan Tabel 2, variabel interaksi antara kebijakan utang dan ukuran perusahaan (DERxSIZE) memiliki koefisien regresi moderasi sebesar (-6,234) dan $t$ hitung sebesar $(-2,417)$ dengan nilai signifikansi sebesar 0.016 yang lebih kecil dari tingkat signifikansi 5\% (0.05). Hal ini menunjukkan bahwa ukuran perusahaan yang diproksikan dengan logaritma natural of total asset mampu memoderasi pengaruh kebijakan utang pada nilai perusahaan dengan arah negatif signifikan yang berarti $\mathrm{H}_{2}$ dalam penelitian ini ditolak. Arah negatif tersebut menunjukkan bahwa ukuran perusahaan memperlemah pengaruh kebijakan utang pada nilai perusahaan.

Hasil studi ini bertentangan dengan penelitian Rizqia, et al. (2013) yang menyimpulkan bahwa perusahaan besar dapat menghasilkan nilai perusahaan yang tinggi mengingat adanya kemudahan perusahaan besar dalam mengakses pendanaan eksternal serta memiliki aktiva yang besar yang dapat dijaminkan dalam sumber pendanaan. Hasil yang berbeda ini dapat dijelaskan dengan teori pecking order.

Teori pecking order menetapkan suatu urutan keputusan pendanaan dimana para manajer pertama kali akan memilih untuk menggunakan laba ditahan, utang dan penerbitan saham sebagai pilihan terakhir (Hidayat, 2013). Berdasarkan teori ini perusahaan pertama kali akan menggunakan dana internalnya sebelum menggunakan utang. Semakin besar suatu perusahaan maka semakin besar pula dana internal yang dimilikinya sehingga semakin sedikit kebutuhan dana eksternal yang dibutuhkan. Oleh karena itu, semakin besar ukuran perusahaan menyebabkan semakin sedikit kebijakan utang yang dilakukan oleh perusahaan sehingga nilai perusahaan juga semakin sedikit dipengaruhi oleh kebijakan utang perusahaan.

\section{KESIMPULAN DAN SARAN}

\section{Kesimpulan}

Penelitian ini menemukan bukti empiris bahwa kebijakan utang berpengaruh positif dan signifikan pada nilai perusahaan. Semakin besar kebijakan utang yang diambil perusahaan untuk memenuhi kebutuhan pendanaan untuk melakukan investasi maupun kegiatan lainnya di dalam perusahaan maka akan semakin tinggi nilai perusahaannya. Lebih lanjut, ukuran perusahaan terbukti secara empiris memperlemah hubungan antara kebijakan utang dengan nilai perusahaan.

\section{Saran}

Penelitian ini memiliki jumlah data yang terbatas dimana data aslinya tidak lolos uji asumsi klasik sehingga dilakukan pengobatan data dengan melakukan transformasi data. Oleh karena itu, 
penelitian selanjutnya dapat mempertimbangkan untuk menggunakan rentang waktu yang lebih panjang sehingga data yang diperoleh lebih banyak dan lebih terdistribusi secara normal. Peneliti berikutnya dapat menggunakan variabel independen lain, seperti kebijakan deviden, profitabilitas, corporate social responsibility, dan good corporate governance sebagai variable yang mampu menjelaskan variasi dari nilai perusahaan.

\section{DAFTAR PUSTAKA}

Agustina, Hilda. "Pengaruh Price Book Value, Earning Per Share, Debt Equity Ratio dan Net Profit Margin terhadap Market Performance Dilihat Dari Share Price dan Return (Sharpe's Measure) Sektor Properti". Skripsi Fakultas Ekonomi dan Ilmu Sosial Universitas Islam Negeri Syarif Hidayatullah. 2008.

Altan, M. and Ferhat Arkan. "Relationship Between Firm Value and Financial Structure: A Study on Firms in ISE Industrial Index". Journal of Business and Economics Research, 9(9), pp: 61-66. 2011.

Antwi, Samuel., Ebenezer Fiifi Emire Atta Mills., and Xicang Zhao. "Capital Structure and Firm Value: Empirical Evidence from Ghana". International Journal of Business and Social Science, 3 (22), pp: 103111. 2012.

Apergis, Nicholas., and Sorros John. "Long-Term Debt and The Value of The Firm: Evidence From International Listed Manufacturing Firms". Review of Economics and Finance Submitted On
14/Sept./2010 Article Id: 19237529- 2011-01-60-13. 2010.

Cheng, Ming-Chang., and Zuwei-Ching Tzeng. "The Effect of Leverage On Firm Value and How The Firm Financial Quality Influence On This Effect". Word Journal of Management, 3(2), pp: 30-53. 2011.

Faisal, Muhamad. "Analisis Pengaruh Free Cash Flow, Set Kesempatan Investasi, Kepemilikan Manajerial, Dan Ukuran Perusahaan Terhadap Kebijakan Hutang". Tesis Magister Manajemen Pascasarjana Universitas Diponogoro. 2004.

Fenandar, Gany Ibrahim. "Pengaruh Keputusan Investasi, Keputusan Pendanaan, dan Kebijakan Dividen Terhadap Nilai Perusahaan". Skripsi Fakultas Ekonomi Universitas Diponogoro. 2012.

Hanarista, Ni Putu Rina Sri. "Pengaruh Kebijakan Dividen dan Kebijakan Utang pada Nilai Perusahaan Dengan Kepemilikan Institusional sebagai Variabel Moderasi”. Skripsi Fakultas Ekonomi dan Bisnis Universitas Udayana. 2016.

Hasnawati, S. "Dampak Set Peluang Investasi Terhadap Nilai Perusahaan Publik Di Bursa Efek Jakarta". JAAI, 9(2), H: 117-126. 2005.

Hidayat, Azhari. "Pengaruh Kebijakan Hutang dan Kebijakan Deviden Terhadap Nilai Perusahaan. Artikel Fakultas Ekonomi Universitas Negeri Padang.

Hidayat, M. Syaifudin. 2013. Pengaruh Kepemilikan Manajerial, Kebijakan Dividen, Struktur Aktiva, Pertumbuhan Penjualan, Dan Ukuran Perusahaan Terhadap Kebijakan Utang. Jurnal Ilmu Manajemen, 1(1), H: 12-25.

Itturiaga, Félix J. López., and Vicente Lima Crisóstomo. 2010. Do Leverage, Divident Payout, and 
Ownership Concentration Influence Firm Value Creation? An Analysis of Brazilian Firms. Emerging Markets Finance and Trade, 46(3), pp: 80-94.

Jusriani, Ika Fanindya dan Shiddiq Nur Rahardjo. 2013. Analisis Pengaruh Profitabilitas, Kebijakan Dividen, Kebijakan Utang, Dan Kepemilikan Manajerial terhadap Nilai Perusahaan (Studi Empiris pada Perusahaan Manufaktur yang Terdaftar di Bursa Efek Indonesia Periode 2009 - 2011). Diponegoro Journal of Accounting. 2 (2). H. 110.

Juhandi, Nendi, et al. (2013). The Effects of Internal Factors and Stock Ownership Structure On Dividend Policy On Company's Value [A Study On Manufacturing Companies Listed On The Indonesia Stock Exchange (IDX)]. International Journal of Business and Management Invention Issn (Online), 2(11), pp: 06-18.

Kontesa, M. 2015. Capital Structure, Profitability, and Firm Value. Whats New? Research Journal of Finance and Accounting, 6 (20), pp: 185192.

Mardiyati, Umi., Gatot Nazir Ahmad., dan Ria Putri. 2012. Pengaruh Kebijakan Dividen, Kebijakan Hutang dan Profitabilitas terhadap Nilai Perusahaan Manufaktur yang Terdaftar di Bursa Efek Indonesia (BEI) Periode 2005-2010". Jurnal Riset Manajemen Sains Indonesia (JRMSI), 3(1), H: 1-17. 2013.

Margaretha, Farah. "Determinants of Debt Policy in Indonesia's Public Company". Review of Integrative Business and Economics. Vol 3 (2). pp. 10-16. 2014.

Meythi. "Dampak Interaksi Antara Kebijakan Utang dan Kebijakan Dividen dalam Menilai Perusahaan”. Jurnal Keuangan dan
Perbankan, 16(3), H: 407-414. 2012.

Nainggolan, Subaraman Desmon Asa., dan Agung Listiadi. "Pengaruh Kebijakan Hutang terhadap Nilai Perusahaan dengan Kebijakan Dividen Sebagai Variabel Moderasi”. Jurnal Ilmu Manajemen, 2(3), H: 868-879. 2014.

Nurhayati, Mafizatun. "Profitabilitas, Likuiditas dan Ukuran Perusahaan Pengaruhnya terhadap Kebijakan Deviden dan Nilai Perusahaan Sektor Non Jasa". Jurnal Keuangan dan Bisnis, 5(2), H: 144-153. 2013.

Ogbulu, Onyemachi Maxwell., and Francis Kehinde Emeni. "Capital Structure and Firm Value: Empirical Evidence from Nigeria". International Journal of Bussiness and Social Science, 3(19), pp: 252261. 2012.

Pradana, Bandem Wicitra Pradnya. "Pengaruh Manajemen Laba Menjelang Initial Public offering Terhadap Return Saham Dengan Ukuran Perusahaan Sebagai Variabel Pemoderasi (Studi Empiris Pada Bursa Efek Indonesia)". Skripsi Fakultas Ekonomi dan Bisnis Universitas Udayana. 2015.

Prasetyorini, Bhekti Fitri. "Pengaruh Ukuran Perusahaan, Leverage, Price Earning Ratio dan Profitabilitas terhadap Nilai Perusahaan". Jurnal Ilmu Manajemen. 1.(1). H:183-196. 2013.

Putri, Anggun Amelia Bahar. "Analisis Pengaruh ROA, EPS, NPM, DER dan PBV terhadap Return Saham". Skripsi Fakultas Ekonomika dan Bisnis Universitas Diponegoro. 2012.

Rizqia, Dwita Ayu., Siti Aisjah., and Sumiati. "Effect of Managerial Ownership, Financial Leverage, Profitability, Firm Size, and Investment Opportunity on 
Dividend Policy and Firm Value". Research Journal of Finance and Accounting, 4(11) pp: 120-130.

2013.

Sudiyatno, B., Elen Puspitasari, dan Andi Kartika. "The Company's Policy, Firm Performance, and Firm Value: An Empirical Research on Indonesia Stock Exchange". American International Journal of Contemporary Research. 2 (12). pp. 30-40. 2012.

Sudiyatno, Bambang and Septavia Mustika Sari. "Determinants of Debt Policy: An Empirical Studying Indonesia Stock Exchange". Educational Research. 4 (1). pp. 98108. 2013.

Sukirni, Dwi. "Kepemilikan Manajerial, Kepemilikan Institusional, Kebijakan Deviden dan Kebijakan Hutang Analisis terhadap Nilai Perusahaan". Accounting Analysis Journal. 1.(2). H: 2252-6765. 2012.

Titman, Sheridan., and Roberto Wessels. "The Determinants of Capital Structure Choice". The Journal of Finance, 43(1), pp: 1-19. 1988.
Vo, Duc Hong., and Van Thanh-Yen Nguyen. "Managerial Ownership, Leverage and Dividend Policies: Empirical Evidence from Vietnam's Listed Firms". International Journal of Economics and Finance, 6(5), pp: 274-284. 2014.

Wiliandri, Ruly. "Pengaruh Blockholder Ownership dan Firm Size pada Kebijakan Hutang Perusahaan". Jurnal Ekonomi Bisnis, 16(2), H: 95-102. 2011.

Yao, S., J. Wang, and L. Song. "Determinants of Social Responsibility Disclosure By Chinesse Firm". Discussion Paper 72. Nottingham: The University of Nottingham. 2011.

www.idx.co.id (PT Bursa Efek Indonesia, diakses 21 September 2016).

www.sahamok.com (diakses 21 September 2016). 